\title{
技術予測一日本とカナタ
}

\section{第三報 パルプ化及び抄紙技術}

\section{Forecasting of Pulp and Paper Technology in Japan and Canada Part III. Pulping and Papermaking Technology}

\author{
東京大学農学部 飯山賢治** \\ (株)日本紙パルプ研究所 可知省吾**, 浅岡 宏*** \\ Kenji Iiyama \\ Faculty of Agriculture, University of Tokyo \\ Shogo Kachi, Hiroshi Asaoka \\ Japan Pulp and Paper Research Institute, Inc.
}

\section{1. はじめに}

カナダ紙パルプ研究所 (PPRIC) が 1973 年 9 月よ り 1 年半かけて実施したカナダ紙パルプ産業の技術と 市場についての予測結果 (K.M. Jegr, K.M. Thompson; "The Canadian Pulp and Paper Industry, Threats and Opportunitties 1980 1990" PPRIC (June, 1975)）と，1975 年 4 月に創設された紙・パル プ技術予測研究会1)（代表幹事近藤民雄九州大学農学 部教授, 中野準三東京大学農学部教授, 浅岡宏(株日本 紙パルプ研究所所長) が，1976 年 2 月より 8 月に実施 した我国の紙・パルプ産業の技術予測の結果（紙・パ ルプ技術予測研究会編; 「紙・パルプ技術予測調査結 果報告書, No. 1〜7」(1976 年 11 月)）について，第 一報 ${ }^{2)}$ で概括的に比較紹介した。また, 第二報3)で我 国の技術予測では一つの項目としてはまとめられてい ないが，カナダではその市場との関係からいくつかの 項目がたてられ，また関連する事項が随所にみられる 新聞用紙に関しての予測結果の比較を行なった。

本報では，我国の技術予測のいわば中心項目ともい らベきパルプ化及び抄紙技術についての予測について， カナダのそれらの予測 (項目 : G. Pulping Technology 及び H. Papermaking Technology) に対応し ながら，両国の紙・パルプ産業のおかれている状況の
違い，その違いからくる考え方の差などを比較し, 更 に両技術子測結果が示唆する今後のパルプ化及び抄紙 技術のあり方についての考察を試みた。

\section{2. 予測を求められた課題}

本報では主としてカナダの技術予測であつかわれた 課題に対応するかたちで，我国の関連する予測結果と を比較するが，はじめにカナダの技術予測のうちパル プ化 (項目 $\mathrm{G}$ ) 及び抄紙技術 (項目 $\mathrm{H}$ ) で予測を求め られた課題を紹介する。

$\mathbf{G}$ : パルプ化技術について

課題 1 今日までの生産量の推移をもとにして, 1980 年及び 1990 年におけるカナダでの全パルプ生産量 を予測せよ。（註：デルファイ法による第 3 回目の 質問では，パルプ生産量を British Columbia 州上 他の地域にわけて答えさせている。)

課題 2 過去 20 年間, カナダでは生産量の増加に加 えて，パルプの種類についてもかなり大きな変化が あった。1980 年及び 1990 年に生産される種々のパ ルプの割合を予測せよ。

課題 3 以下の項目が丰現する時期（5年きざみで） を子测せよ。

(1)カナダでリファイナー确木パルプ（以下 RGP と 略す）がメカニカルパルプの $25 \%$ となる。

* 第二報 : 本誌, 31, 366 (1977)

** 紙・パルプ技術予測研究会事務局員

$* * *$ 同副代表幹事 
(2)北米での新聞用紙生産量の $25 \%$ が，100\%メカニ カルパルプで製造される。

(3)カナダで砕木パルプ（以下 GP と略す）を混合し たサーモメカニカルパルプ (以下 TMP と略す) がティシュ及びある種の印刷用紙につかわれる。

(4)100\% TMP でできた新聞用紙がカナダの全新聞 用紙の $10 \%$ を占める。

(5)アルカリ性サルファイトパルプ（以下アルカリ性 $\mathrm{SP}$ と略す) 及びソーダパルプ(以下 AP と略す) 法がカナダで央用化される。

(6)現在の化学パルプ製造法にかわる新しい非硫黄パ ルプ化法が開発され，カナダで実用段階に入る。

(7)クラフトパルプ（以下 KP と略す）の平均収率が 60\% まで上昇する。

(8)樹皮つきチップを用いた化学パルプ化法が開発さ れ，カナダで実用化される。

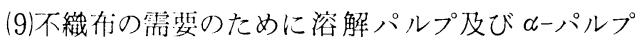
の生産量が少くとも現在の 2 倍になる。

(10)酸素㱫白パルプがカナダの全漂白パルプ生産星の $25 \%$ を占める。

(11)他のガス状漂白（ $\mathrm{Cl}_{2} \mathrm{O}, \mathrm{ClO}_{2}$ 等を用いた）が開 発され，カナダで央用化される。

(12)力ナダのすべての工場で，漂白薬品回收が実用化 される(漂白廃水は回収工程にもどされる)。

(13)針葉樹材を用いた全材パルプ化及び漂白法がカナ ダで工業化される。

課題 4 全材パルプ化及び漂白は紙質にどのような影 響を及ぼすか。

課題 5 どんな種類のパルプが古紙におきかえられ， どのよらな製品になるか。

\section{H：製紙技術について}

課題 1 カナダにおいて新しい紙首形成法はどの程度 まで実用化するか。1980 年及び 1990 年にカナダの 紙生産に用いられる種々の紙層形成法の割合を予測 せよ。

課題 2 次の紙質の標準偏差值が現在の值の $1 / 2$ にな る時期を子測せよ。

(1)坪量, (2)含水率, (3)厚さ。

課題 3 技術的, 経済的及び壊境仢にみて, カナダの 製紙工場の $25 \%$ で水のクローズ化が実用化される 時期を予測せよ。

課題 4 物理的限界や騒音など, 技術的, 経済的にみ て, 以下の事項は将来どうなるか予測せよ。

(1)最大級の抄紙機での最高設計生産能力。

(2)最大設計抄速

課題 5 カナダでの紙製品中の化学パルプ平均含有率

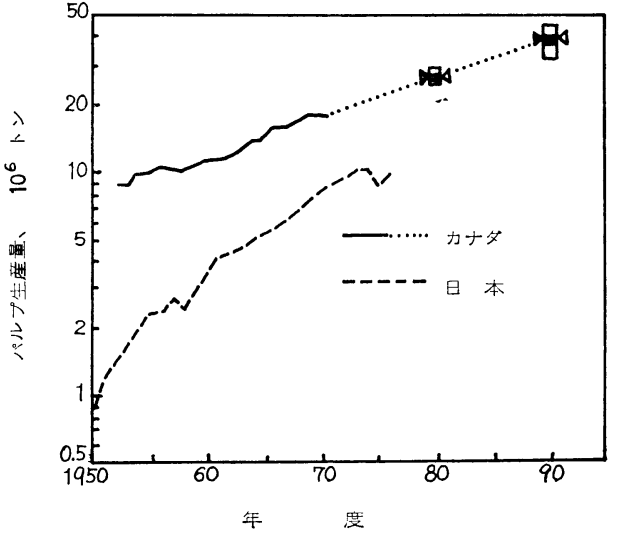

図 1 全パルプ生産量の推移と尒測結果

は, メカニカルパルプ (TMP 及びケミメカニカル パルプ（以下 CGP と略す）を含む）の改質によっ て低下すると考えられているが，下記製品中の化学 パルプ及びメカニカルパルプの平均的比率を予測せ よ。

(1)新聞用紙，(2) GP 印刷用紙，(3)他の印刷用紙， (4)特殊紙（衛生紙を含む）（5)コンテナボード， (6)ボックスボード，(7)工作用紙及び板紙。

課題 6 下記製品に用いられる繊維物質の割合を予測 せよ。

(1)新聞用紙，(2)ライナーボード，(3)中しん原紙， (4)折畳みボックスボード，(5)非折畳みボックスボー ド，(6)固状漂白ボックスボード，(7)その他のボック スボード，(8)GP 印刷用紙，(9)その他の印刷用紙， (10)包装紙，(11)ティシュ及び衛生紙，(12)工作用紙及び 板紙。

以上に対応する我国での予測については，その都度 ふれることにする。

\section{3. パルプ生産量について}

図1にカナダでの技術予測の質問の際に付された 1950 年代から今日までのカナダにおけるパルプの年 間全生産量の推移を, 我国におけるパルプ生産量の推 移4)とともに示す。このデータをもとにして予測され た結果は, 1980 年には現在 (1970 年 1,830 万 t)の 1.4 倍の 2,600 万 $\mathrm{t}$ より，1990年には 1970 年の 2.1 倍 である 3,800 万 $\mathrm{t}$ よなって, 今後も年間 $4 \%$ 弱づつ生 産量は増加するということであった。

1980 年の予測值のバラツキは比較的少なかったが, 1990 年のそれはかなりバラツキがみられる。IQR (第 1 四分位数と第 3 四分位数の範囲) より高い生産量を 予測した人は,「カナダは引続いて世界の主要なパル 
プ供給国であって, 1980 年代になると再生産可能な木 材繊維への需要が高まり, 成長率も高くなる」とのコ メントをつけており, 逆に IQR より低い生産量を予 測した人は，「奥地森林資源の開発をよぎなくされ， 木材コストが上昇するとともに, インフレと高利子が 引続くと考えられることもあって大規模な工場を多数 新設することは困難であり, 生産量の伸びはおさえら れる」との意見を出している。しかし我国と違って興 味深いのは, IQR より低い值を予測した人（すなわ ちより悲観的にみている人）から「環境問題もある 程度は影響するが, 繊維需要には大きな変化はないで あろら」といらコメントが出されていることであり， 同様なことは中間値を予測した人からも言われている ことである。

我国の技術予測では, 生産量予測はなされていない。 我国での現在までの生産量の推移をみると, カナダよ りかなり成長率は高いようである。パルプ生産量では ないが, 全世界の紙・板紙需要量については, Keays 5) 及び FAO (国連食糧農業機構) $)^{6)}$ で予测されてい るが, Keays は過去の需要の推移から, それらが継続 すると考えて, 1975 年に 16,500 万 $\mathrm{t}$ (1970 年から 75 年の平均年間成長率 $4.9 \%$ ) だった紙・板紙需要量は, 1980 年には 21,000 万 $\mathrm{t}(1975$ 年から 80 年の平均年間 成長率 4.9\%)，1990 年には 30,000 万 $\mathrm{t}$ (1980 年から 90 年の平均年間成長率 $3.6 \%$ ) になるとしている。 $\mathrm{FAO}$ の結果では 1980 年 22,000 万 $\mathrm{t}(1975$ 年から 80 年の年間平均成長率 $5.9 \%), 1985$ 年には 27,600 万 t （1980 年から 85 年の平均年間成長率 $4.6 \%$ ） と急激な 増加となっている。このようにいずれにしても 1990 年ごろまでは, 今回のカナダの技術予測でみられたよ 万に, 年成長率 4 5\% 程度が維持され, 生産量は指 数関数的に増加すると考えられており, パルプの高収 率化や古紙回収による再利用がはかられるにしても， 同時に指数関数的に增加するであろう木材供給をどう 保障していくか, 興味あるところである。またこれら の予測に掞いては, 木材瀻維及び紙・板紙製品の利用 形態の変化, 利用の集約化 (例えば軽量化等) などが あまり考虑されていないと考えられる点は問題がない とはいえないだろう。

\section{4. 全パルプ生産量に占める各種パルプの比率}

\section{1 クラフト及びサルファイトパルプ}

図 2 にカナダにおける各種パルプの生産比率の年度 変化及び 1980 年, 1990 年の予測值を, 図 3 亿我国の 各種パルプの生産比率の変化を示す。 $\mathrm{KP}$ は臭気問題 があるにもかかわらず，その問題は都市近郊から離し

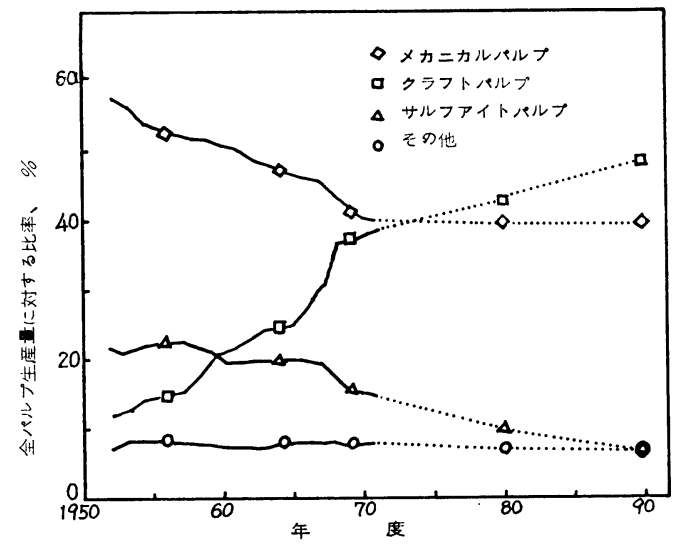

図 2 カナダに扔けるパルプ生産比率の推移と予 測結果 (ケミメカニカルパルプはメカニカ ルパルプに, セミケミカルパルプはその他 に含まれる。)

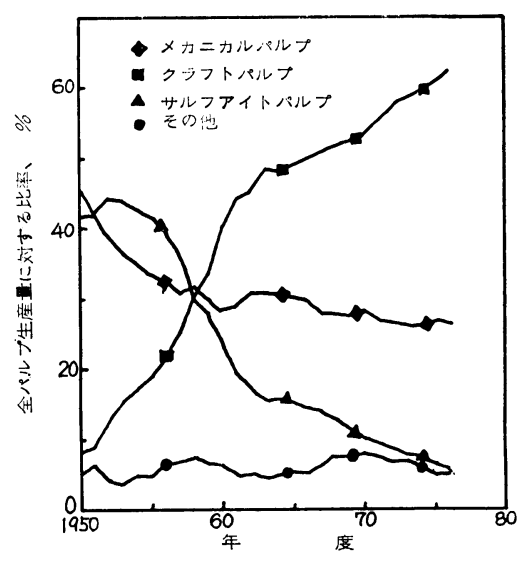

図 3 我国におけるパルプ生産比率の推移 (ケミメカニカルパルプはメカニカルパル プに，セミケミカルパルプはその他に含ま れる。)

て設置することによって，また他の方法で解沃され， 強度への要求からより主要なものになってくる。しか し, メカニカルパルプより高い此率を占める木材コス トの上笲及び製品でのメカニカルパルプとの競合, 非 硫黄パルプ化法など新しいパルプ化法の出現によって, 現在の成長率は維持できず, 成長率は低くなると予測 されている。

一方サルファイトパルプ (以下 SP と略す) は新聞 用紙への化学パルプ混合率の低下, 低強度及び污染負 荷が高いなどの理由で堿少するが，ベース交換や污染 の制御などがほどこされるため, 完全になくなるとい 
うことはなく生き残ると考えられている。 SP に関し て與味深いのは 1 回目の回答に付されたコメントに 「リグニンケミカルスとしての需要のため SP は增加 するだろう」というがあり，第 2 回目の回答に際して はこのコメントに賛成する人はなく，逆に「過去 50 年閂, リグニンケミカルスの試みがなされているにも かかわらず，何ら成果があがっていない」「そうなれ ばすばらしいのだが!!」とのコメントが付されていた ことである。

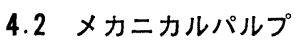

カナダでは 1950 年代に全パルプ生産量の $50 \%$ 以上 を占め，パルプ生産の中心となっていたメカニカルパ ルプ（カナダの場合には CGP を含めている）は, 1970 年には 40\% に低下してきている。しかし，(1木 材資源の有效利用, (2)污染負荷が少ない, (3)化学パル プを混合しなくてもよいような新しいメカニカルパル プ製造法の確立などによって，1980 年，1990 年にか けて生産量の絶対量は増加し, 全生産量に上める割合 は40\%程度でほとんど変化しなくなるだろらと予測さ れている。更に表 1 に示すように，メカニカルパルプ の改良によってすべての紙製品に占めるメカニカルパ ルプの割合の壃加によるメカニカルパルプの需要の増 大も，この颉问を促進寸ると考えら机ている。また古 紙による代替については，占紙パルプ製造による污染 負荷の增大のため，あまり影響されないと考えられて いる。

メカニカルパルプの生産量に関しては我国の技術予 測でも,「No. 2 高收率パルプ編」で数課題ふれられ ている。我国のメカニカルパルプのパルプ全生産量に 対する生産比率は，主に「中下級紙だけに用いられ， 高成長分野であった印刷, 産業用紙分野には入れなか った」こともあって, 図 3 に示すようにカナダの比率 よりかなり低く（CGPをのぞいたメカニカルパルプ だけでは 1960 年 $28.6 \%, 1970$ 年 $15.4 \%, 1974$ 年14.8 \%)，漸减傾向にあったが，今後 1985 年までにストー ン GP は 1974 年の生産量の $1 / 2$ 以下になるものの, (1)比引裂強さが大きく, 結束繊維の少ない7) TMP の 開発，実用化，(2)リファイナーの改善による RGP 製 造法の改善, (3品質改良による印刷, 産業用紙への進 出, (4)原木難, などによって增加に転じ, 1986〜1990 年の間には全パルプ生産量の $30 \%$ を占める, すなわ ち現在の比率の約 2 倍 (GP, RGP だけで)，(実現度 80\%) と予測されている。更に全パルプ生産量の 19.1 \%（1974 年）を占めていた CGP 及びセミケミカル パルプ (以下 SCP と略す) も増加し，1985 年〜1990 年には $30 \%$ 程度（実現度は $60 \%$ とあまり高くはない
表 1 種々の紙・板紙製品のメカニカルパルプ含 有率の変化 $(\%)$

\begin{tabular}{|c|c|c|c|}
\hline 紙・板 紙製品 & $\begin{array}{l}\text { 1970年 } \\
\text { 丢 績 }\end{array}$ & 1980年 & 1990年 \\
\hline 新 聞 用 紙 & 75 & 82 & 90 \\
\hline G P 氏 刷 用 紬 & 70 & 75 & 80 \\
\hline その他の泪刷・筆他用紬 & 8 & 10 & 15 \\
\hline 特殊 組（衛生紙を含む） & 25 & 30 & 35 \\
\hline コンテナボード & 3 & 10 & 18 \\
\hline ボックスボード & 20 & 25 & 35 \\
\hline 工 作 用 縕・枚 紙 & 28 & 35 & 43 \\
\hline
\end{tabular}

が）になると予測されているこょを考えると, 現在全 パルプ生産量の $60 \%$ 以上を占めている KP がどらな るのか, 不明な点も残されている。なお, メカニカル パルプが $30 \%$ を占めるようになった時には, 全メカ ニカルパルプの $30 \%$ は TMP になると考えられてい 石（実現度 $100 \%) 。$

\section{3 新しいメカニカルパルプ製造法-TMP-}

カナダの予測結果でふられている「新しいメカニカ ルパルプ製造法」には TMP も含まれていると考え られ，両国とも TMP に対する期待が非常に大きい。 TMP の原理はいらまでもなく, チップをリグニンの 軟化点 (二次転移点) 以上の温度に加熱し, 破断する ことによって結束繊維を少なくするとともに, リファ イニング動力を減少させるといらものであるが，加熱 によるリグニンの軟化によってリファイニング動力は 減少するものの, 加熱のためのエネルギーが必要であ って,トータルとしては省エネルギーにならない辛と 考えられ，省エネルギーパルプ化といらことには必ず しもならない。しかし, 最近比引裂強さだけでなく, 此破裂強さ, 裂断長も大きい, より紙質が改良され, しかもリファイニング動力もより少ない TMP といら ことで, チップを亜硫酸ソーダ又はカセイソーダで前 処理する方法" ${ }^{9)}$ 研究され, 実用化されてきており, このような改良も含めて, 今後より一層 TMP への期 待が高まるものと考えられる。

\section{4 その他のパルプ}

カナダにおいては「その他のパルプ」（SCP を含 む) は, 1970 年までは全パルプ生産量の $8 \%$ 程度でほ ぼ一定であったが, メカニカルパルプと同様に, 今後 絶対量は増加するものの比率は現状とほぼかわらない と考えられている。この「その他のパルプ」の中では 「省資源, 省エネルギー」といらことで, 収率 75〜90 
\%程度のパルプ化, すなわち SCP が重要視されてい るが，酸素・アルカリ蒸解は設備に大きな資本が必要 であるとともに，製品の強度が低く，またソーダのバ ランスがとれないなど問題をかかえ，今すぐ実用化さ れるといらよりも，むしろ 2000 年位までの長い目で みて有力になってくるというコメントが付されている。

また末閒発の新しいパルプ化法がありうるか否か上 いうことに関して，「過去 70 年間に基本似に新しいも のとしては, 1930 年代に開発された中性サルファイト セミケミカルパルプ (以下 NSSC と略す) と， 1950 ～1960 年代に開発された RGP であったにすぎず，今 後現在のパルプ化法の改良法はできたとしても, 経済 的になりたっていけるような新しいものは困難であ る」との意見が出されていた。

\section{5 革新的パルプ化法}

以上のようにカナダでは強度への需要の故に, KP の大幅な伸びと, TMP 等の出現によるメカニカルパ ルプの現状維持（絶対量は増加するが）が-予測されて おり，いわゆる「新しいパルプ化法」の出現にはさほ ど大きな期待を寄せていない。

木材資源問題，環境問題がカナダと比較にならない 位きびしくうけとめざるを得ない我国でも，TMP の 出現によるメカニカルパルプの生産量の大幅な増加を 予測しているが，同時に我国では KP 製造時の关気対 策は 1985 年までに㬰用化（実現度 90\%）するとして いるものの，KP 蒸解時にかなり多量に発生する硫化 水素, メチルメルカプタン, ジメチルスルフィド, ジ メチルジスルフィド10) とテルペンとの合成臭気である 臭気は，Weber-Fechner の法則により成分を $99 \%$ 減少させても 2 単位しか低下せず，人家から隔離して $\mathrm{KP}$ 工場を設置する条件にない我国では，完全に対策 をたてることは困難といわざるをえない。そこで我国 の技術予測ではホロパルピング，酸素ーアルカリ蒸解 などへの期待も強く，紙質や経済性に問題はあるとは しながらも，1990年までには酸素・アルカリ蒸解が 1,000 t/年（実現度 74\%）になり，さらに 1990 年には ホロパルプ, 酸素・アルカリパルプを含めた現在の化 学パルプより 5 10\% 収率の高い非硫黄系パルプの実 用化が実現する（実現度 95\%）と予測されている点は 異っている。

更に我国では先にも述べたが，100\%とはいかない までも，排水規制の強化によって， CGP, SCP の薬 液回收法が 1985 年までに普及し，CGP 及び SCP は 1985 年に全パルプ生産量の約 30\% になる（1974 年実 績は 19.1\%)（実現度 60\%）との予測があるとともに， CGP 及び SCP 製造法についても具体的に, Worster
11)の提案した炭酸ソーダを用いる广法（Worsterの方 法は，6\% 炭酸ソーダで， $170^{\circ} \mathrm{C} ， 30$ 分䦌処理）や, スルホメチル化，オゾン処理に加えて，例えばアクリ ル酸のグラフト化 ${ }^{12)}$ ，スルホン化 ${ }^{13)}$ など竌水性基の導 入等による高収率パルプの改質の可能性（斍水性基導 入による改質については，1990仹までに些現し，夷 現度 $90 \%$ と㝋测）についても子机ている。このよう に我国では技術的队谷について子机ることができたの は，第一㣮でふれたようにカナダでは间签者中に占め る専門家の割合があまり望くなかったが，我国の今回

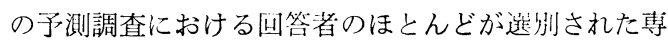
門家であったことによるであろう。

しかしながら「現在の技術の延長線上にあるものに ついては子測可能だが，そうでない革新的技術につい ての予測は困難である」 ${ }^{14)}$ というデルファイ法の弱点 もあって，いわゆる「革新的技術」については，雨国 の調查ともほとんどふれられていない。ただ一行では あったが，カナダの報告書の別の項目のところで， "Use of laser or sonar in pulping" ( のレーザー又は超音波の使用」）とふれられ，「パルプ 化への微生物の利用」ということが我国の予測にコメ ントとして付されていたにすぎない。パルプ化への微 生物，バクテリア及び酵素の利用，すなわち “Biological pulping”はスウェーデンにおいて, Henningsson ら ${ }^{15)}$ が研究を進めており, 多くの解決しなければ ならない問題はあるが，我国では例えばチップ船中又 は野積み中での部分的蒸解などの可能性もなきにしも あらずであろう。なおこの点については最近総説 ${ }^{16)}$ 出されている。

また，パルプ化へのレーザーの応用については現在 にいたってもまだ一件の報告もみられないが，極めて 単色性の優れたコヒーレントな強力な光源であるレー ザー光を照射することによって，(1)赤外部である特定 の振動準位を励起して化学反応をおこさせる，(2)強力 なレーザーより発生する高熱を利用して反応をおこさ せる，(3)通常の条件で反応しない 2 つの化合物の混合 系にレーザー光を照射して，一方の化合物をいったん 活性種に化学変化させて他の一方の分子と熱反応をお こさせる, などが可能 ${ }^{17)}$ であることから, 例えば蒸解 中のリグニンの $\beta$-アリルエーテル結合の選択的開裂 による脱リグニンの促進や, 酸素や塩素などを励起さ せて反応させるなど応用は不可能ではないであろう。 なお, 高分子のガラス転移点の降下や流動時間等の短 縮をもたらすことが知られている超音波, 高周波のパ ルプ化への利用も考えられなくはないと思われる。

更にこれら以外にも，現在研究がす寸められている 
表 2 カナダにおけるパルプ化及び漂白技術の実現時期（回答者率，\%)

\begin{tabular}{|c|c|c|c|c|c|}
\hline & 実 & 現 & 時 & 月 & \\
\hline 項 & ～1980年 & ～85年 & ～90年 & ～95年 & 非実現 \\
\hline 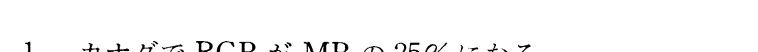 & 47 & 47 & 6 & 0 & 0 \\
\hline 1. カナダで RGP が MP の 25\% になる。 & 45 & 50 & 5 & 0 & 0 \\
\hline 2 背光- & 2 & 21 & 59 & 13 & 5 \\
\hline 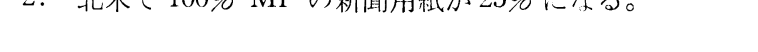 & 0 & 16 & 63 & 16 & 5 \\
\hline 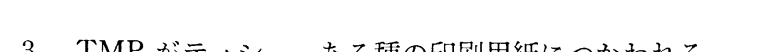 & 47 & 32 & 13 & 8 & 0 \\
\hline 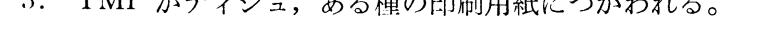 & 59 & 12 & 12 & 7 & 0 \\
\hline 4 カ十ダで $100 \%$ TMP の新閒用紙が $10 \%$ てか & & 36 & 59 & 0 & 0 \\
\hline 4. & 0 & 44 & 56 & 0 & 0 \\
\hline 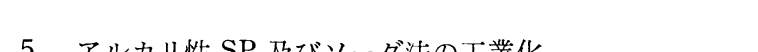 & 22 & 19 & 0 & 22 & 37 \\
\hline 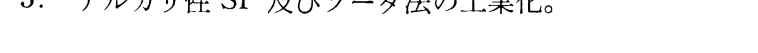 & 17 & 17 & 0 & 24 & 42 \\
\hline 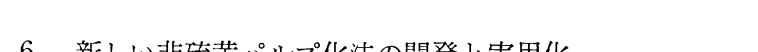 & 14 & 43 & 29 & 14 & 0 \\
\hline 0. 秃しい非䂱㕣ハルフ化法の的光と夹用化。 & 13 & 47 & 20 & 20 & 0 \\
\hline 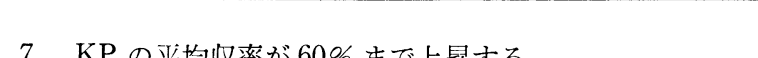 & 0 & 11 & 24 & 24 & 41 \\
\hline 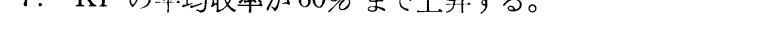 & 0 & 8 & 15 & 23 & 54 \\
\hline 8 樹皮つきチップの化学パルプ化法の聞登と害田化 & 62 & 20 & 5 & 5 & 8 \\
\hline 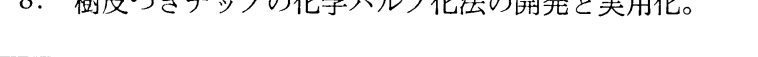 & 67 & 13 & 0 & 7 & 13 \\
\hline 9 DP & 0 & 21 & 9 & 49 & 21 \\
\hline 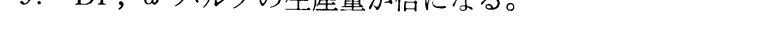 & 0 & 21 & 7 & 36 & 36 \\
\hline 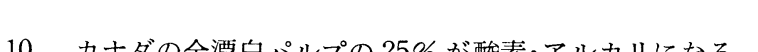 & 0 & 17 & 69 & 8 & 6 \\
\hline 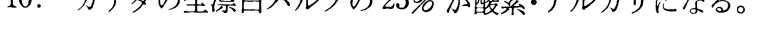 & 0 & 7 & 64 & 22 & 7 \\
\hline 11他のガス状酒白が聞登さわ 害田化子 & 53 & 36 & 8 & 0 & 3 \\
\hline 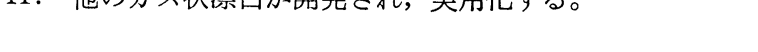 & 50 & 36 & 7 & 0 & 7 \\
\hline 12 洒白获员の回帆がナぶての丁坦で宅田化 & 3 & 57 & 20 & 14 & 6 \\
\hline 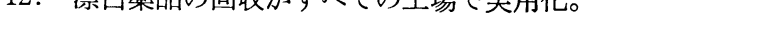 & 0 & 53 & 20 & 20 & 7 \\
\hline 13. 針葉樹の全材パルプ化の丁業化 & 12 & 56 & 20 & 3 & 9 \\
\hline & 26 & 53 & 7 & 7 & 7 \\
\hline
\end{tabular}

*: 上段 : 全回答者, 下段 : 専門家

$\mathrm{MP}:$ メカニカルパルプ, RGP : リファイナーグランドウッドパルプ, TMP : サーモメカニカルパルプ,

$\mathrm{SP}:$ サルファイトパルプ, KP : クラフトパルプ, DP : 溶解パルプ

ものとしては, 水媒体中での $r$ 線照射, 電子線照射に よって生成した・OH，・OOH などのラジカルの蒸解 への利用又はパルプの改質 ${ }^{18)}$ なども考えられるだろう。 これら「革新的技術」については, 今後の研究の進展
をみながらその可能性をさぐっていきたいものである。

\section{5. パルプ化及び漂白法について}

カナダにおけるパルプ化及び漂白に関する 13 の事 
項についての実見予测絬果を表 2 に示す。以下第 2 表 に示した項目を(1)メカニカルパルプ製造に関して，(2) $\mathrm{KP}$ の高収率化と新しい化学パルプ製造に関して，(3) 漂白技術に関して, (4)その他, と整理して記述する。

\section{1 メカニカルパルプ製造に関して}

先にも述べたように, 我国とカナダでは集部の仕う

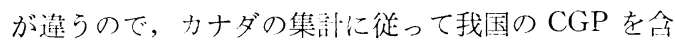
めてメカニカルパルプとして考えると, 我国では 1976 年度で RGP は全メカニカルパルプの約 30\%（全パ ルプ生産量の $8 \%$ ）に達し, 今後 1985 年までに, 例え ば高压リファイニング19)などリファイニングの改良に よって改質された RGP の実用化が進む（実現度 80 \%) と考えら机ているが，カナダでも RGP の生産が 增し，1985 年までには全メカニカルパルプの $25 \%$ を 占める（実現度 $94 \%$ ）上うになると考えられてい る。

このように今後のメカニカルパルプ製造法として, ストーン GP より比引裂強さの大きな TMP 及び RGP が期待されており，TMP 及び RGP などによ るメカニカルパルプの紙質の改良によって，100\%メ カニカルパルプ又は 100\% TMP の新聞用紙の出現が， カナダでもまた我国でも街ち望まれている。カナダの 予測では, 北米で 100\% メカニカルパルプの新聞用紙 が全新聞用紙生産量の $25 \%$ になるなは 1990 年（実現 度 82\%)，カナダの新聞用紙の 10\% が 100\% TMP か ら製造されるようになるのはやはり 1990 年（実現度 100\%）となっている。我国でも生産量は問われてい ないが, 1985 年までに化学パルプ $5 \%$ 以下の新聞用紙 がつくられる（実現度 95\%）と予測されている。しか し両国とも，現状の紙質，印刷速度がそのときまで継 続していった場合には可能であ万らが，軽量化及び印 刷速度の高速化が進んだときには問題は残るとのコメ ントが付されている。更にカナダの予測では 100\% メ カニカルパルプの新聞用紙を実現するためには, 具体 的にはふられていないが，新しいメカニカルパルプ製 造法の開発が必要とも述べられている。その点で裂断

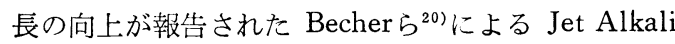
法, 及び引裂強さが TMP 以上に優れた，チップにア ンモニアを含浸させた後，急激な降圧，爆䂶によるア ンモニア爆研法 ${ }^{21}$ なども，TMP とともに新しいメカ ニカルパルプ製造法として期待されるであろう。また 前章で述べたように，製造されたメカニカルパルプに 親水性基などを導入してパルプの改質をはかる方法の 開発も含めて考える必要があろう。

省資源, 低污染負荷のメカニカルパルプは両国とも 今日以上に期待されているが，それをささえる用途の
抬大が娭討されねね゙ならない。この点についてカナダ ではティシュ及び印刷用紙としてのTMP ひ用途の拡 大 (1985 年まで, 実現度 79\%) が期待されており, 我国でもメカニカルパルプの含有率が 30 40\% のテ ィシュの実現 (1985 年まで, 実現度 97\%), 上質紙一 のメカニカルパルプの利用 (1990 年拣で, 垁現度 80 \%) がされると期待されている。しかし，「柅用用紙に メカニカルパルプを添加する点に関しては, 高收率パ ルプの白色度, 退色性, 印刷番性などの開題があり, 技術的には可能であっても高級品指向といら現在の消 費者の趣向の変化がないとむずかしいといら意罗が我 国のアンケートに付されており，「メカニカルパルプ 在含む印刷用紙が我国の全印刷用紙の $80 \%$ を占める ようになる」という設問に対して央現度は 60\% (1990) 年まで）と他に比べて低くなっている。

\section{$5.2 \mathrm{KP}$ の高収率化と新しい化学パルプ製造に関} して

カナダでは今後 $\mathrm{KP}$ が大きく伸びパルプ熦造の主力 となると予測されているが，省資源といら立場から高 収率化の実現が期待されている。しかし収率 $60 \%$ の KP は実現しないか，したとしても熱回仪などの問題 もあって 1990 年以降になる上回答した人が $65 \%$ を占 めている。我国では收率が 2 5\% 高い KP は 1985 年 までに実用化する（実現度 93\%）上予測されているが， これはポリスルフィド蒸解, 硫化水素前処理又は緑液 処理によって実現すると考えられており，尖気問題と の関係がどうなるのか心配な点もある。しかし最近， 反応メカニズムは不明であるが，KP 蒸解液及びソ一 ダ蒸解液に $0.1 \%$ 程度という極く少量のアントラキ, ン系の薬品を添加することによって, 収率を $5 \%$ 程度

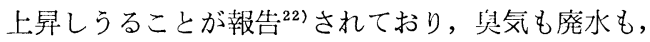
また製品の着色もさほど問題にならずに高收率を実現 する KP 蒸解の改良法が開発されてきている。

寸でに指摘したようにデルファイ法による未来予測 では現在の技術の延長線上にある技術, 又はすでに開 発され, 実用化の一歩手前までいっている技術が今後 どうなるかという予测は可能だが，まったく新しく， まだ検討もされていないような革新的技術を予測する ことは困難である。両国の技術予測にも, 新しい化学 パルプ製造法についてふれられているが，それらは上 記の範囲を出ていない。

カナダでは(1)アルカリ性サルファイト蒸解, ソーダ 蒸解法の実用化, (2)非硫黄系蒸解法の実用化, につい て予測が求められ，前者については回答者の $60 \%$ の 人が，実現したとしても 1990 年以降になるだろうと している。しかし後者については, 酸素・アルカリ蒸 
解などによって $57 \%$ の凷答者が 1985 年までに，また $86 \%$ の人が 1990 年までに先垷すると考えている。

我因の技術甬测においては回答者の尃門度が高いこ ともあってここの点はより其体的に検討されており， ソーダ蒸解, アルカリ性サルファイト㻑解, 紙パルプ 矿究所で開発されたホロパルピング (PFP 法), 東洋 パルプで開発された凌素・アルカリ烝解法の一つであ る HOPES 法，さらに「微生物によるパルプ化」な ど無奥化蒸解が 1990 年までに全化学パルプの $30 \%$ を 超す（実現度 $80 \%$ ) と考えられている。しかし，優れ た紙質をもつ KP の放棄につながる非硫黄系蒸解を 考えなくても，KP の密䦌化，臭気成分の捕集，釜内 酸化などによる無県化，低奥化の実現（1985年まで， 央現度 90\%)によって考えればよいとの見方もある。

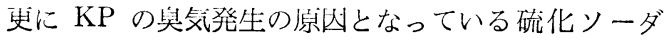
にかわる薬品が央現するかどうかも予湘されているが, これについては回收工程も含めて硫化ソーダにとって かわるような楽占稆垷の川能性はあまり高くない (1990 年まで，央現度60\%) としている。しかし前述 のように，アントラキノンのソーダ蒸解液への添加は 実現可能なものの一つといえよう。更に硫化ソーダに かわるといらものではないが，強度的にも KP 匹敵 し，しかも收率が5\%程度高いアルカリ・メタノール 蒸解法 ${ }^{23)}$ は, メタノールの価格及び回収法の確立によ って央用化される途もあるように思われる。この蒸解 のメカニズムについては, 㔀近リグニンのベンジル位

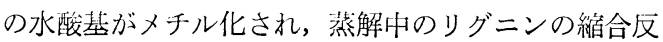
応を妨害し，脱リグニンを谷易にするとともに，セル ロースのピーリング反忘の阻止によって高収率化と強 度増加がもたらされることが明らかにされた

\section{3 漂白技術に関して}

カナダの技術了测では湛白に関し，(1)酸素漂白，(2) $\mathrm{Cl}_{2} \mathrm{O}, \mathrm{ClO}_{2}$ などによるガス状漂白，(3)漂白薬品回収， がふれられ，我国では，(1)高収率パルプの過酸化水素 以外の酸化漂白及び亜二チオン酸塩以外の還元漂白, (2)酸素漂白を含む盐素系以外の多段漂白, (3)漂白のク ローズド化，がふれられている。

酸菜漂白は淤染負衔が少ないなどの利点をもつため, すでに実用化が進んでいるものの，コストが高く，強 度が低く，さらに薬品バランスがとれないなどの理由 から，カナダで酸系漂白が全漂白法の $25 \%$ をこすの は1990 年になるだろら（実垷度 86\%）と予測されて いる。なお当然のことながら，この予測にあたっては 何よりも現在用いられているマグネシウム塩より優れ た炭水化物のプロテクターの開発が鍵であるとのコメ ントが付されている。プロテクターの挙動については
近年精力的に研究が進められてきており,例えばC-13 NMR を用いてキレート形成による作用などが明らか にされてきている25)。

一方我国では工場立地がカナダとは大きくことなり， 色色規制なども含めて廃水規制が緟しくなると考えら れることから，カナダの予測で指摘された欠点はある ものの，酸素漂白への期待は大きく, 1985 年までに酸 溪漂白が30\%をこし（実現度 93\%)，さらに1995 年 までには 50\%をこす（実現度 90\%）と考えられてい る。また同時に廃水規制との関係から 1990 年までに 漂白のクローズド化が 20\% 以上になる（実現度 93\%） と予測されているが，この点はカナダの予測でも 1990 年までには漂白はクローズド化され，薬品回収が実用 化する（実現度 80\%）と考えられている。

カナダでは $\mathrm{Cl}_{2} \mathrm{O}$ や $\mathrm{ClO}_{2}$ など㙁素系漂白剤による 高濃度ガス状漂白の実用化が予測され，これはかなり 早い時期（1985 年まで，実現度 89\%）に実現すると 洘えられているが, 高品質の新聞用紙用の新しいRGP 澿白法の必要性も指摘されている。この点我国では具 体的に, 過酸化水素又は亜二チオン酸塩にかわる酸化

(例えばオン゙ン, 酸䒺, 過酢酸) 及び還元剤（例えば 水素化ホウ素ナトリウム) の実用化が予測されている が，主に経済的な理由により，前者については 1990 作 (実現度 $80 \%$ )，後者については同じころであろう が央現度は $60 \%$ と低くなっている。なお前述したが， カナダの予測ではこの項目で「パルプ化へのレーザー 及び超音波の使用」がコメントとして付されている。

\section{4 その他}

カナダの予測では以上のメカニカルパルプ及び化学 パルプ製造法, 漂白技術に加えて, 樹皮つきチップ及 び全材パルプ化 (whole tree pulping), 漂白に関す る項目がたてられている。樹皮つきチップについては すでにコンテナボード用 KP 及び NSSC として広範 に使われており，早い時期に実用化 (1980 年; 実現度 62\%，1985 年; 実現度 82\%) すると考えられている。 また, 全材パルプ化及び漂白についても, 白色度, ゴ ミの混入及び強度低下などの問題もあり, 今後の研究 の重要性が指摘されているものの, 資源問題との関連 から 1985 年までに実用化（実現度 68\%，1990 年まで は実現度 88\%) すると予測されている。我国ではこの 問題はカナダ以上に深刻であるにもかかわらず, 我国 の予測ではふれられていない。

更にカナダの予測では, 紙質への全材パルプ化への 影響について具体的に検討されており, 蒸解能力の低 下及び漂白コストが増大してメリットはなく, 枝, 葉 などは予じめ分別して然料などに用いた方がコスト的 
にも安く，効果的であるとの否定的な意見もあるが， 低級紙としては十分利用できるといら見方も出されて いる。しかし，回答者の多くは全材パルプ化のために は技術開発が必要であり，その技術開発はなされると 考えている。

\section{6. 古紙による木材パルプの代替について}

カナダでは 1974 年の古紙回收率は $12 \%$ ，利用率は $6 \%$ と我国の $40 \%$ 及び $37 \%$ に比へ，木材資源が豊富 なこともあって極めて低い (OECD 加盟諸国の平均で 回收率 $27 \%$ ，利用率 $24 \%$ ）が，古紙の利用について は大きな與味がはらわれ，第一報1に示したように $\ulcorner\mathrm{F}$. 回収再生䌦維の供給」の項目で主にふれられて いる。ここでは回収された古紙がどのように再生利用 されるかといらことが检討されており，その結果の一 部を表 $\mathbf{3}$ 及び表 $\mathbf{4}$ 亿示すが，特传術との関連でとら れているわけではない。結論としては大部分のパルプ は古紙で代替されらるうるが，実際に代替されるには 古紙の品質と価格が問題となってくるといらことであ る。

我国の予測においても「古紙」を課題としてとりあ げ，検討しているが，そこでとりあげられている項目 の多くはカナダの場合の「回収再生繊維の供給」の課 題と同じで，「回収技術，選別技術，古紙の劣化」な どの間題が中心としてあつかわれており, 古紙のパル プ化に関する技術的課題についてはあまりふれられて いない。しかし, 技術進歩及び需要構造の変化にとも なって，板紙の古紙消費原単位は 1985 年までに 0.70 をこえ (1968 1974 年は 0.60，実現度 95\%)，また 1968 1974 年まで 0.12 0.14であった紙の古紙消費 原単位む 1985 年までに 0.30 をこえる（実現度 86\%) と予測されている。またそのときまでには，40\%程度 の古紙回収率は $45 \%$ に上昇（実現度 96\%）し，さら に 1990 年までには $50 \%$ (実現度 78\%) に達し，「試算 による古紙回収率の限度である $57 \%$ にせせると考え られている。しかし，現在手がつけられていない都市 塵芥中にも紙，布，木材など瀻維原料も含まれている が、これからパルプを製造しようとする試み尚もなさ れており，これが実現すれば回収率はさらに引上げら れよう。

この古紙再生は省資源といらことは当然のこととし， さらに一旦繊維化したものを用いるのであるから省エ ネルギーにつながる。また, 古紙の再生には蒸解工程 がないため BOD, COD 廃出負荷が低下するといら 利点はあるものの, SS の水質污染負荷量の増大, 脱 インクによる廃水着色の問題もあり, 再生繊維の紙質
の問題とともに，これらの処理技術も今後検討される 必要があろう。

\section{7. 抄紙一紙層形成法について}

紙層形成法が今後どのように変化していくかという ことについて，カナダ及び我国でも多大な関心をよせ， 予測が行なわれている。カナダでもまた我国でも，そ の高速性, 軽量紙化, 品質管理の䘱易さ及び表褰差の ない紙の需要の伸びなどによって, 低速性能, 地合, 㙫 料歩留, 㬝間強度, 印刷適性などの改善を荘する点も あるが, ツインワイヤーが今後伸びていくだろう（表 5)。しかし, 現在の主才である長網式を一挙にツイン ワイヤーにきりかえるにはあまりにも転換コストが高 くつくため, 急速な伸びといらのではなく, スクラッ プアンドビルドによって徐々に切りかえられると考え られている。なお，我国の予測においてはツインワイ ヤーでの紙層形成時間は従来のものより1ケ夕短かく, コンマ数秒であって, 從来の静的脱水挙動の検討では だめで, その動的検討, 評洒の方法の確立が必装であ る,とのコメントが付されている。

乾式抄紙法は無公害抄紙という点では重要であり, 我国では廃水規制次第では実用化にむかっていくこと もありえよう。しかし，セルロースの膨鬥や分散，地 合形成には水がなくてはならず，水による水素絬合形 成にかわるような繊維間結合をさせることは技術的に も，また経済的にもひきあわず，契用化されたとして も極く一部の品種, 例えばティシュ, ボード等に限定 されるだろうというのが, 両国の一致した予測絬舁で ある。

高濃度抄紙（我国の予测設問では $2.5 \sim 4 \%$ と考え ている）は, 地合の問題及び厚さ方向の強度の問題空 かかえているが，污染及びエネルギー問題から重要視 され, 繊維の均一分散法や連続沪水管理技術などが近 々開発されて, 我国でもまたカナダでも 1985 年ごろ までには実用化されると考光られている。カナダの子 測では現在使われなくなってきている円網式マシンも， 古紙の再利用の増加にともなって部分的に利用される ようになると考えられている。

我国の予測では以上の現在稼動中か, 実用一歩手前 にある紙凮形成法だけでなく, テストプラントでは成 功している不透明性の高い発泡抄紙法の実用化及びこ れもテストプラントで成功している Strata-F!o-Headbox など新しい紙層形成法に関しての設問もある が, ディスポ, 軽量紙, 薄物では発泡抄紙法は 1990 年までに実用化（実現度 81\%）され，また 1985 年ま でには新しい紙層形成法が開発される（実現度 100\%） 
表 3 古紙によって代替されるパルプと製品

\begin{tabular}{|c|c|c|c|c|}
\hline \multirow{2}{*}{ 代替されるパルプ } & \multirow{2}{*}{ 古 } & \multirow{2}{*}{ 製 } & \multicolumn{2}{|c|}{ 回答者(人) } \\
\hline & & & 賛 成 & 反 対 \\
\hline メカニカルパルプ & 新聞用紙 & $\begin{array}{l}\text { 新聞用紙,印刷, 筆記用紙,ダンボ } \\
\text { ール,ボックスボード, ティシュ }\end{array}$ & 31 & 0 \\
\hline 末漂白クラフトパルプ & $\begin{array}{l}\text { ダンボール，封筒用紙 } \\
\text { 紙袋古紙 }\end{array}$ & $\begin{array}{l}\text { ライナー, 中芯原紙, 包紙, 紙袋, } \\
\text { ボックスボード }\end{array}$ & 22 & 0 \\
\hline $\begin{array}{l}\text { 中忹サルファイトセミ } \\
\text { ケミカルパルプ (NSSC) }\end{array}$ & ダンボール & $\begin{array}{l}\text { ライナ一, 中しん原紙, ボックス } \\
\text { ボード, 下級紙 }\end{array}$ & 20 & 0 \\
\hline 新聞紙用パルプ & 新聞紙 & 新聞用紙 & 18 & 1 \\
\hline 短繊維パルプ & & $\begin{array}{l}\text { 新聞用紙，ダンボール，ボックス } \\
\text { ボード }\end{array}$ & 16 & 1 \\
\hline $\begin{array}{l}\text { 多くのパルプ（古紙の品質 } \\
\text { と価格によっている。） }\end{array}$ & & 大部分の製品 & 10 & 0 \\
\hline 漂白化学パルプ & 高級な白古紙 & $\begin{array}{l}\text { 印刷・筆記用紙，ティシュ， } \\
\text { 衛生紙 }\end{array}$ & 21 & 0 \\
\hline
\end{tabular}

表 4 紙・板紙中の古紙繊維の割合

\begin{tabular}{|c|c|c|c|c|c|}
\hline \multirow{3}{*}{\multicolumn{2}{|c|}{ 悢・板 紙 }} & \multicolumn{4}{|c|}{ 古 紙 の 割 合 (\%) } \\
\hline & & \multicolumn{2}{|c|}{ 1980年 } & \multicolumn{2}{|c|}{ 1990年 } \\
\hline & & 全 回 答 者 & 專 門 家 & 全回答者 & 專 門 家 \\
\hline 新聞用紙 & $\mid \begin{array}{ll}\text { 平 } & \text { 均 } \\
\text { 範 } & \text { 团 } \\
\end{array}$ & $\begin{array}{c}0.2 \\
(0 \sim 10)\end{array}$ & $\begin{array}{c}0.3 \\
(0 \sim 3)\end{array}$ & $\begin{array}{c}2 \\
(0 \sim 10)\end{array}$ & $\begin{array}{c}2 \\
(0 \sim 5)\end{array}$ \\
\hline ライナー & $\mid \begin{array}{ll}\text { 平 } & \text { 均 } \\
\text { 籁 } & \text { 团 }\end{array}$ & $\begin{array}{c}16 \\
(7 \sim 25)\end{array}$ & $\begin{array}{c}16 \\
(7 \sim 20)\end{array}$ & $\begin{array}{c}22 \\
(10 \sim 40)\end{array}$ & $\begin{array}{c}20 \\
(12 \sim 30)\end{array}$ \\
\hline 中しん原紙 & $\left|\begin{array}{ll}\text { 平 } & \text { 均 } \\
\text { 筙 } & \text { 团 }\end{array}\right|$ & $\begin{array}{c}16 \\
(5 \sim 90)\end{array}$ & $\begin{array}{c}12 \\
(8 \sim 20)\end{array}$ & $\begin{array}{c}26 \\
(8 \sim 30)\end{array}$ & $\begin{array}{c}20 \\
(10 \sim 26)\end{array}$ \\
\hline $\begin{array}{l}\text { 折䁷み } \\
\text { ボックスボード }\end{array}$ & $\begin{array}{|ll|}\text { 平 } & \text { 均 } \\
\text { 範 } & \text { 圆 } \\
\end{array}$ & $\begin{array}{c}38 \\
(25 \sim 42)\end{array}$ & $\begin{array}{c}36 \\
(30 \sim 40)\end{array}$ & $\begin{array}{c}50 \\
(35 \sim 60)\end{array}$ & $\begin{array}{c}48 \\
(45 \sim 50)\end{array}$ \\
\hline $\begin{array}{l}\text { 非折疊み } \\
\text { ボックスボード }\end{array}$ & $\begin{array}{|ll|}\text { 平 } & \text { 均 } \\
\text { 籁 } & \text { 团 }\end{array}$ & $\begin{array}{c}60 \\
(40 \sim 80)\end{array}$ & $\begin{array}{c}57 \\
(50 \sim 60)\end{array}$ & $\begin{array}{c}63 \\
(50 \sim 68)\end{array}$ & $\begin{array}{c}62 \\
(50 \sim 65)\end{array}$ \\
\hline その他のボックスボード & 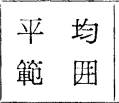 & $\begin{array}{c}52 \\
(35 \sim 90)\end{array}$ & $\begin{array}{c}50 \\
(40 \sim 55)\end{array}$ & $\begin{array}{c}60 \\
(45 \sim 90)\end{array}$ & $\begin{array}{c}60 \\
(50 \sim 75)\end{array}$ \\
\hline 印刷用紙 & $\begin{array}{|ll|}\text { 平 } & \text { 均 } \\
\text { 範 } & \text { 因 } \\
\end{array}$ & $\begin{array}{c}4 \\
(1 \sim 10)\end{array}$ & $\begin{array}{c}4 \\
(3 \sim 6)\end{array}$ & $\begin{array}{c}5 \\
(3 \sim 10) \\
\end{array}$ & $\begin{array}{c}5 \\
(4 \sim 8)\end{array}$ \\
\hline 包紙 & $\begin{array}{|ll|}\text { 平 } & \text { 均 } \\
\text { 範 } & \text { 团 } \\
\end{array}$ & $\begin{array}{c}1 \\
(0 \sim 4)\end{array}$ & $\begin{array}{c}1 \\
(0 \sim 2)\end{array}$ & $\begin{array}{c}3 \\
(0 \sim 10) \\
\end{array}$ & $\begin{array}{c}2 \\
(0 \sim 10) \\
\end{array}$ \\
\hline ティシュ, 衛生紙 & $\begin{array}{|ll|}\mid \text { 平 } & \text { 均 } \\
\text { 範 } & \text { 囲 } \\
\end{array}$ & $\begin{array}{c}4 \\
(2 \sim 10)\end{array}$ & $\begin{array}{c}5 \\
(2 \sim 10) \\
\end{array}$ & $\begin{array}{c}5 \\
(3 \sim 20) \\
\end{array}$ & $\begin{array}{c}7 \\
(3 \sim 20) \\
\end{array}$ \\
\hline 工作用紙・板紙 & $\mid \begin{array}{ll}\text { 平 } & \text { 均 } \\
\text { 籁 } & \text { 国 } \\
\end{array}$ & $\begin{array}{c}35 \\
(10 \sim 90)\end{array}$ & $\begin{array}{c}35 \\
(30 \sim 50) \\
\end{array}$ & $\begin{array}{c}40 \\
(33 \sim 90) \\
\end{array}$ & $\begin{array}{c}41 \\
(35 \sim 60) \\
\end{array}$ \\
\hline
\end{tabular}


表 5 カナダにおおる紙層形成法の変化

\begin{tabular}{|c|c|c|c|c|c|c|}
\hline \multirow{3}{*}{\multicolumn{2}{|c|}{ 紙 層 形 成 法 }} & \multirow{3}{*}{ 1973年実績 } & \multicolumn{4}{|c|}{ カナダの全紙生産量に対する割合（\%) } \\
\hline & & & \multicolumn{2}{|c|}{ 1980年 } & \multicolumn{2}{|c|}{ 1990年: } \\
\hline & & & 全回答者 & 専 門 家 & 全回答者 & 曹 門 家 \\
\hline 長 網 式 & $\begin{array}{l}\text { 平 均 } \\
\text { 範 因 }\end{array}$ & 94 & $\begin{array}{c}82 \\
(70 \sim 90)\end{array}$ & $\begin{array}{c}82 \\
(70 \sim 90)\end{array}$ & $\begin{array}{c}61 \\
(45 \sim 80)\end{array}$ & $\begin{array}{c}60 \\
(50 \sim 80)\end{array}$ \\
\hline ツインワイヤー & $\begin{array}{l}\text { 平 均 } \\
\text { 範 明 }\end{array}$ & 6 & $\begin{array}{c}17 \\
(10 \sim 30)\end{array}$ & $\begin{array}{c}17 \\
(10 \sim 26)\end{array}$ & $\begin{array}{c}37 \\
(25 \sim 50)\end{array}$ & $\begin{array}{c}38 \\
(20 \sim 50)\end{array}$ \\
\hline 乾式抄紙 & $\begin{array}{l}\text { 平 均 } \\
\text { 範 四 }\end{array}$ & 0 & $\begin{array}{c}1 \\
(0 \sim 3)\end{array}$ & $\begin{array}{c}1 \\
(0 \sim 3)\end{array}$ & $\begin{array}{c}2 \\
(0 \sim 5)\end{array}$ & $\begin{array}{c}2 \\
(0 \sim 5)\end{array}$ \\
\hline $\begin{array}{l}\text { その他 } \\
\text { (円網式など) }\end{array}$ & $\begin{array}{l}\text { 平 均 } \\
\text { 籁 囲 }\end{array}$ & 0 & $\begin{array}{c}+ \\
(0 \sim 2)\end{array}$ & $\begin{array}{c}+ \\
(0 \sim 2)\end{array}$ & $\begin{array}{c}+ \\
(0 \sim 2)\end{array}$ & $\begin{array}{c}+ \\
(0 \sim 2)\end{array}$ \\
\hline
\end{tabular}

と予測されている。カナダではこれらに関してはふれ られていない。だがその内容は不明であるが，おそら く合成ポリマーの接着に用いられていることからの発 展として，「二層形成への高周波の利用」といらコメ ントが付されていることは指摘しておいた方がよいで あろう。

\section{8. 紙質の管理について}

カナダの予測では, 抄紙時における坪量, 水分量及 び厚さのバラツキが制御され, そのバラツキの標準偏 差が $1 / 2$ になるのはいつごろか, といら質問がされた。 しかしこの設問に対し,「現在の標準偏差值が示され ていないので回答しにくい」といら意見, また「現在 の值で十分でありそこまでする必要もない」「そこま でするにはコンピュータ制御が必要であって, 旧式の マシンでは経済的にひきあわない」とのコメントもあ ったが，坪量，水分量及び厚さともに 1980 年までに 1/2 にできると答えた人が過半数いた。そして 1990 年 までには回答者全員が実現すると回答している。これ に直接対応する設問は我国にはないが，「紙の最終製 品特性（下記のうち一つでも）が抄紙機上で自動的に 検查可能になる。(肌, 代表的紙力, 表赛差)」がある がこれによると代表的紙力に関しては光学的手段で 非接触オンライン測定が 1985 年までに可能になるだ ろら（実現度 89\%）と予測されている。しかしそれら 測定值をフィードバックし, 自動的に制御しらるかど らかについてはふれられていない。

\section{9. 製紙工場における水のクローズド化につい $\tau$}

「カナダの全製紙工場の $1 / 4$ で水のクローズド化が 実用化するのはいつか」とのカナダの設闘に対して, カナダの回答者の何人かの人は「パルプ工場における 水のクローズド化」と勘違いして答えているという面 もあったが, 専門家の $75 \%$ の人は, 繊維及び熱の国 仪, 污染負荷の減少がせまられていることもあって, 1985 年までに実現すると予測している。

我国でも $84 \%$ の回答者が 1985 年までに製紙工場に おける水のクローズド化は実現すると答えている。し かし両国とも完全にクローズド化するにはあまりにも コスト高になってしまらので, 完全にはならず, 用水 原単位が現在の $1 / 5$ 程度 (日本) にすればよいのでは ないかとのコメントが付されていた。カナダではこれ が実現するかどうかは政府の規制にかかっているが, カナダの工場は都市から離れて立地しており, また水 量が豊富なこともあってクローズド化する必要がない のではないかとのコメントに対する賛成者もおり,こ の点でも我国の工場立地との違いを思い矨らされる。

\section{0. 新聞用紙用マシンの動向}

この点については第二報3) で詳しくふれているので, 簡単にふれるにとどめるが，カナダにおいては新聞用 紙用の最大設計能力の抄紙機で, 生産能力は 20 万 $\mathrm{t} /$ 年 $(1973$ 年) から 25 万 $\mathrm{t} /$ 年 (1980 年), さらに 27.5 万 $\mathrm{t} /$ 年 (1990 年) になり, また抄速は $4,000 \mathrm{ft} /$ 分（約 $1,220 \mathrm{~m} /$ 分) (1973 年) 加ら $4,500 \mathrm{ft} /$ 分（約 $1,370 \mathrm{~m} /$ 
分）(1980 年)，さらに $5,000 \mathrm{ft} /$ 分（約 $1,520 \mathrm{~m} /$ 年） (1990 年) になると予測された。今後の抄紙機の動向 としては, 幅もスピードも增すと答ええた人は少なく (回答者の 23\%)，高速化に対応するワインダーの改 良（2 ワインダー化も含めて）を経て，幅は変らず現 在のままで高速化するようになり，しかも自動化が進 展すると考えられている。

この点について我国の予測でも新聞紙用マシンでは, 現在の $1,000 \mathrm{~m} /$ 分が 1985 年までに $1,500 \mathrm{~m} /$ 分になり

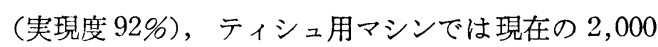
$\mathrm{m} /$ 分が 3,000 m/分 (1990 年, 実現度 $80 \%$ ), コータ 一用マシンでは $1,000 \mathrm{~m} /$ 分が $1,500 \mathrm{~m} /$ 分 (1985 年, 実現度 $91 \%$ ）になるなど高速化し，幅は現状の約 10 $\mathrm{m}$ が経済的, 技術的限界であり, 幅の増加はないと予 測されており，カナダの結果とよく一致している。し かし我国の予测に扔いては, 需要から考えて我国でこ れだけの高速化を必要としないし, 高速化は必ずしも コスト低下につながらないといらコメントがつけられ ている。

また，カナダの予测ではマシンの自動化及び一人の 作業員が多くの単位をらけもちらるような省力化した 小型マシンの必要性を指摘する人があり, 我国でも紙 切れ対策などのため無人化は実現しないが, 省力化は 進むと予測され，抄紙機の複雑さと抄紙のノウハウの 問題がなげかけられていた。

\section{1.おわりに}

以上，一部分整理したところもあるが，できるかぎ りカナダの予測を基本にし，それに我国の予測内容を 対容を対応させるようにして, 両国のパルプ化及び抄 紙技術に関する予測結果を紹介，検討してきた。本稿 をまとめるにあたって，例えば我国では重視している がカナダの予測に沶いては廃水処理技術にふれていな いなど，工場立地条件の差による環境問題のとらえ方 の差, 資源状沅の差, 製品市場の差などによる両国の 紙・パルプ産業のおかれている状況の違いをおもいし らされた。その違いによって，パルプ化及び抄紙技術 について総体的にみ机ば，カナダではすでに実用化さ れている技術が今後どうなっていくかといらことが予 測の中心にあり，我国ではそれに加えて，どんな新し い技術がでてくるか，それをどう実用化していくかと いう積極的な面を合んでいるといら違いとして表われ ているように思われた。ただこの差は両国の紙・パル プ産業のスティタスの差だけでなく, 今回の予測に対 して回答した人の専門度が我国が極めて高く, カナダ は低いといらことによってもたらされているのかもし
れない。対応する設問に対する回答は，我国の方が全 般的に楽観的であり，この点にもよりきびしい状況に おかれている我国の紙・パルプ産業の現状が反映して いるのであろう。

而国の予測ともデルファイ法でなされたため, 個々 の予測結果を関係付けてみると若干矛盾する結果もで ている点もあり, また現在未開発の技術, 特に現在の 技術の延長線上では考えられない革新的技術について はふれれられられていない。本稿ではそれらについて著 者の責任で若干のコメントを付してきたが，技術予測 の信頼性をより高め, 利用しうるようにするためには, 今後これらの点を補っていく努力ものぞまれる。

また, この技術予測を単に予測としてだけで終らせ るのではなく, 実現するためにはこれから何が必要な のかを, 例えば両国の予測調查に回答者として加わっ た専門家の間の討論などで明らかにしていくことが必 要ではないかと痛感した。

\section{文 献}

1）中野準三：紙八゚技協誌，30 (2)，71 (1976)

2）浅岡 宏, 可知省吾, 飯山賢治: 同上, 31, 246 (1977)

3）可知省吾, 浅岡 宏, 飯山賢治 : 同上, 31, 366 (1977)

4）紙パ技協誌「統䛅」から集計

5) J.L.Keays : Tappi, 58 (No. 11) 90 (1975)

6) C.W.Wettergren : ibid., 58 (No. 12) 77 (1975)

7) R.P.Pecke : Pulp \& Paper, 1975 (No. 6) 108

8) G.Gavalin : Svensk Papperistidn., 77, 189 (1974)

H.Haglund, et al.: Tappi, 59 (No. 6) 144(1976)

9) R.Leask : Pulp Paper Canada, 76, T-294 (1975)

10) K.Wndersson : Svensk Papperistidn., 73, 1 (1970)

11) H.E.Worster : Paper Trade J., 157 (No. 34) 31 (1973)

12) Th.Krause, M.McGahin, J.Schurz : Das Papier, 29, (10A) 6 (1975)

13) K.P.Kringstad, J.Olausson : Svensk Papperistidn., 77, 480 (1974)

14）紙・パルプ技術予測研究会編「紙・パルプ技術予 測調查結果報告書, No. 3 無公害パルプ編」 p. 36 (1976) 東京

15) B.Henningsson, M.Henningsson, Th.Nilsson : Department of Forest Products, Royal College 
of Forestry, Research Notes, No. R. 78, “Defibration of Wood by the Use of a White-rot Fungus" (1972), Stockholm.

V. Westermark, K. Eriksson : Acta Chem. Scand., B 28, 209 (1974)

16）近藤民雄 : 紙八技協誌，31，306（1977）

17) 吉原経太郎 : 応用物理, 44, 1205 (1975)

P.H.Kim, K.Taki, S.Namba : Bull. Chem.

Soc. Japan, 48, 2953 (1975)

C.A.Sawicki, Q.H.Gibson : J. Biol. Chem., 251, 1533 (1976)

E.W.Fu, P.P.Dymerski, R.C.Dunbar : J. Am. Chem. Soc., 98, 337 (1976)

18）森 見二, 佐々木透, 花村憲男 : 紙パ技協誌, 31, 54 (1977)

K.Hunt : Tappi, 59 (No. 10) 89 (1976)

G.A.Nicholls, L.Lindevall, G.W. Mitchell : ibid., 57 (No. 11) 91 (1974)

D.Atack : Svensk Papperistidn., 75, 89 (1972) 稲葉政満, 飯塚堯介, 中野準三 : 昭和52年度纎維 学会年次大会講演要旨集，p.80（1977 年6月） 東京

19) W.M.Orchard, M.T.Charters : Tappi, 56, 142 (1973)

20) J.J.Becher, G.R.Hoffman, J.W.Swanson : Ta- ppi, 59 (No. 1) 140 (1976)

21) J.J.O'Conner : Tappi, 55, 353 (197'2)

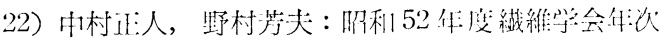
大会諽演恶旨集，p.86(1977年6月) 東宗

H.H.Holton : Canadian Industries Limited Chemicals Research Laboratory, Technical Report "The Major New Process, The Soda Additive Palping of Softwoods" (1977) McMasterville, Quebec.

23）中野準三，需塚千代子，李佘潘，小林正明，偖々 木坤彪：第 25 回日本木材学会大会講演要旨集, p. 133 (1975 年 4 月) 福阔 中野準三，高塚千代子，大間歪紀：紙分技協誌， 30, (12) 33 (1976)

24）大間秀紀，細谷修二，中野準三：紙パルプ技術協 会第 40 回研究発表会偝演要旨集, p. 13 (1977 年: 6 月) 東京

大間秀紀，絒谷修二，中野準三：木材誌，22， 539 (1976)

25) J.Defoye, H.Drigues, A.Gadelle : Applied Polymer Symposium, 28, 955 (1976)

26）御田昭雄, 町田 収, 加来武彦: 紙パルプ技術喘 会第 40 回研究発表会諈演裂旨集，p.19（1977年: 6 月) 東京 